\title{
Transition from a Despotic Racism to a Chaotic Freedom: An Althusserian Reading of Nadine Gordimer's My Son's Story
}

\author{
Shahram Raeisi Sistani \\ Assistant Professor, Department of Foreign Languages, Faculty of Humanities, \\ Bahonar University of Kerman, Kerman, Iran \\ shahram.sistani@uk.ac.ir
}

Doi:10.5901/mjss.2014.v5n23p2491

\begin{abstract}
Nadine Gordimer has examined two types of ideologies in some of her novels. It is because her country and generation have observed a despotic racist ideology and a newly established democracy consequently. She places herself in the middle of these two turbulent realms to diagnose the wicked parts of them. In My Son's Story (1990) she examines the psychological impacts of prevailed ideologies upon the psyches of common people. She tries to seek some panaceas for these fractured psyches through her fictional works. My Son's Story gives an account of endeavor and delusion of South African people in their fight for freedom. The socio-political reality of the country under a biased ideology is disclosed through the perceptions of the narrator. This paper tries to rely upon Louis Althusser's concept of ideology to give a new reading of the novel. Althusser's perception of freedom as an ideology in shaping people's consciousness shows the role of ideology in the establishment of social relationships. It brings to the light the interaction between education, society, and freedom. In the novel we come across with particular situations as naturally true. Gordimer makes a significant contribution in literature by bring them into the surface. She delineates the ways of legitimating the power of the ruling class in society. Characters in the novel are unaware of the ideology which surrounds them. They try to shape their identities based on this unconsciously. The ways in which people are controlled through the prevailing ideology will be discussed in the light of Althusserian theory of ideology.
\end{abstract}

Keywords: Education; freedom; identity; ideological State Apparatuses; Racism

\section{Introduction}

Nadine Gordimer (1923 - ) is considered one of the prominent writers of contemporary world. In her works she is always obsessed with the pathetic experiences of individuals in their question of ideology. Her works are considered unique for the reason that she depicted the apartheid as well as post apartheid worlds. The tensions and dilemmas which clearly are portrayed in her novels are saturated with the structures of reproducing the unequal relations as normal. Her novels produce an awareness by which people are allowed to be conscious of themselves. She brings to the light ways of legitimating the act of those in charge of the society. In My Son's Story she gives an account of the families struggling for freedom. Ideologies under the oppressive apparatuses are delineated through the consciousness of the narrator. He narrates a journey to freedom and subjectivity. The protagonist "Sonny" is a black teacher and a hero in his fight against ideological apparatuses. His story which is narrated through his son "Will" is an ex post facto. He appraises freedom over equality as it is shown in these few lines from the text, "Equality was not freedom; it had been only the mistaken yearning to become like the people of the town. Who wanted to become like the very ones feared and hated? Envy was not freedom." (Gordimer, 1990, p.23 henceforth Gordimer)

As a school teacher he has devoted himself to the enlightenment of next generation. By enlightening the people he wants to transform them to more sensitive citizens. As a matter of fact, he wants to help them to become self conscious subject. Literary works like My Son's Story brings to the light not only,

The myths and imaginary versions of real social relationships which constitute ideology, but also that classic realist fiction, the dominant literary form of the nineteenth century and arguably of the twentieth, 'interpellates' the reader, addresses itself to him or her directly, offering the reader as the place from which the text is most 'obviously' intelligible, the position of the subject in (and of) ideology. (Belsey 1988, p. 47)

Gordimer in this novel is obsessed with the formation of ideology. Ideology in her novel is something more than a fantasy. It is inscribed in the fact of education of colored people. Sonny helps the people in their search for resistance and identity in this way, "he was approached to form a local committee, has elected to a regional executive, he studied 
government white papers in the tin-trunk archives of township proclamations, and title deeds old people had kept; he stood on the creaking boards of a church hall and made his first speech ... words too, are stones" (Gordimer, p.32). In the beginning Sonny is depicted a self conscious fellow. He is not a one dimensional man. He reacts to the prevailing social apparatuses not only as a father but also as an instructor. His affection for his country and people is depicted in the context of being part of a place where has been stolen from him. The novel gives no signs of a bright future and any hope for sincere transformation. Different forms of resistance that are used by the people are scrutinized. The writer wants to inform people of their responsibilities in their struggle for freedom. Sonny the protagonist dedicated himself to the education of the next generation. He thinks by acquiring education a person can get equality as well. Such dreams have nothing to do with the ideology which is prevailed in the society. Gordimer's attitude with regard to Sonny's efforts is depicted in the relationship between education and freedom. She questions the complex interplay between education, freedom, and ideology. The current ideology is interrogated in an effort to demonstrate how racism has been interpolating its doctrine into the education of common people. Sonny's movement towards individuation and freedom provides a brilliant example of how freedom may be compromised as the ideological state apparatus of racism places ruling class principles into the vanguard of society.

Gordimer in My Son's Story imagines a society free from walls and class barriers. Her humanistic vision dismisses all attempts of Ideological State Apparatuses. The conflicts between different classes of society are abundant in the novels of her. These conflicts accords with Althusser's rereading of Marx that what is represented in ideology is "not the system of the real relations which govern the existence of individuals, but the imaginary relation of those individuals to the real relations in which they live" (Althusser 1971, p.155). According to Althusser ideology exist in the behavior of the people act in accordance with their belief. For instance, Sonny's sense of service to the community is not based on some illusions, but on his own need for self respect. Althusser is one of the major thinkers who have put their impact upon the study of ideology in the contemporary world. He believes that most of our actions are products of social principles. Althusser (2003) in his ground breaking essay entitled, "Ideology and Ideological State Apparatus" remarks that ideology is a collection of images and stories. The ways in which people construct their relationship to the society is considered real and make their existence meaningful. But there is the other layer for the ideology as well. This part that generally is conceived as imaginary disapproves any attempts for appreciation of the ways in which people are socially constituted. The ways people are acting based on their imagination and dreams are called ideology. It means the current ideology is hard to make out due to the lies and class barriers.

\section{Discussion}

My Son's Story represents imaginary versions of real social apparatuses which constitute ideology. It is a story of constant struggle and disappointing loss of a belief. There is a pessimistic view about the future and the chance for real transformation in the novel. The racial relationship under an oppressive system is disclosed through the consciousness of a young subject. As a whole the story is about Sonny's real and imaginary relation to the world. It is real in that it is the way that he really lives his relationship to the social relations which govern his existence. At the same time it is considered imaginary in that it discourages a full understanding of this condition of existence and the way in which he is socially constituted within them. Sonny is a school teacher. He is considered an icon in his struggle against South African apartheid. Different types of strategies are taken by black people in their resistance to apartheid. Indifference is one of these strategies. In the novel we come across comments such as, "What did it matter that the seaside hotels, the beaches, pleasure grounds with swimming pools were not for us? We couldn't afford hotels, anyway." (Gordimer, p. 21)

However, Sonny is one of characters who do not believe that the power which held the subjects exists only in the real world. The unresponsiveness of the colored subjects is unable to assure the safety and security of their lives under apartheid system. They simply knew that there is no escape from ideology because they live in the ideology. It is here that Sonny like others became aware of his own responsibility in his struggle. Sonny values freedom over equality in this way, "Equality was not freedom; it had been only the mistaken yearning to become like the people of the town. Who wanted to become like the very ones feared and hated? Envy was not freedom" (Gordimer, p. 23). This statement accords with Althosser's definition of ideology. He avers "ideology is a, "representation" of the Imaginary Relationship of Individuals to their Real Conditions of Existence." (Althusser 2003, p. 693)

Sonny's sense of responsibility towards his country is based on his own need for self-respect. It is in accord with this attitude that he dedicates himself to the education of kids. But he is unaware that ideology is a set of illusory ideas imposed upon common people by an evil system. According to Althusser the real ideology is dictated by the institutions of this system. He calls such system Ideological State Apparatuses (IASAs). Sonny thinks by educating children he gives them equality with whites. The central ideology in Sonny's society is the educational system. The way he urges his wife 
Aila to wind up her social activities is clearly depicted in this line from the text, "it is humiliating to take from them, Aila, let them have it." (Gordimer, p.40)

Sonny wants to show the change that they need is change in view point in their attitude with regard to the whites. In this process the role of family and literature is very prominent. Because they assist people in reproducing the myths and ideologies needed for working within the same social structure. Anyway, all ideologies are constructed for the forming of subjects. As Althusser remarks, "I say: the category of the subject is constitutive of all ideology, but at the same time and immediately I add that the category of the subject is only constitutive of all ideology insofar as all ideology has the function (which defines it) of 'constituting' concrete individuals as subjects" (Althusser 1971, p.160). Within the ideology the role of subjects like Sonny is quite distinguishable. Mostly because he is able to use language in a correct way. He is capable to posit himself as 'l'. Emile Benveniste also believes that it is in language that people form themselves as subjects. The constitution of 'I' is only possible when the constitution of 'non-l' is taken into consideration. "Language is possible only because each speaker sets himself up as a subject by referring to himself as I" (1971, p. 225). He also claims, "it is literally true that the basis of subjectivity is in the exercise of language. If one really thinks about it, one will see that there is no other testimony to the identity of the subject except that which he himself thus gives about himself" (p.226). The social structure which is depicted in the novel never allows the colored people like Sonny to introduce or define themselves. In a simple term, the society never takes into consideration the formation of 'non-l'. Attaining subjectivity in the fictional world of Gordimer is possible when characters, "learn ... to trust in what they know, as well as how they are known by others... this double liberation is the closest thing to the attainment of religious knowledge in Gordimer's narratives." (Clingman 1986, p. 15)

Language provides Sonny a better view point towards the ideology. In Post-Saussurean term, language by differentiating between concepts offers the possibility of meaning. Sonny's desire towards learning is a sign of his desire to stand above his social status and to find new concepts and words through which to convey his ambitions and dreams. This attitude of him reminds us Jacques Derrida's statement,

what was it that Saussure in particular reminded us of? That 'language [which consists only of differences] is not a function of the speaking subject'. This implies that the subject (self-identical or even conscious of self-identity, selfconscious) is inscribed in the language, that he is a 'function' of the language. He becomes a speaking subject only by conforming his speech...to the system of linguistic prescriptions taken as the system of differences.... (1973, p. 145-6)

In his search for subjectivity Sonny values freedom over equality. Sonny teaches his students how to use language to become a unique and free subject. Education is meant to bestow them equality with whites. In Lacanian term, subjectivity is not given, but acquired. It is because of this that Lacan believes the infant is at first, "a little man and also like a broken egg spreading without hindrance in all directions." (Coward and Ellis 1977, p.101)

In Lacanian psychoanalytic, a subject acquires identity during the mirror stage the moment when it recognizes a strange unity for the first time. It is able to distinguish itself from the world. This recognition means to identify with an imaginary self. This image is distinguishable only in the mirror world. As a matter of fact, it is misrecognition. It means, to be able to act consciously under social construction, the subject must be involved in symbolic order. It is symbolic that is related to the language and narrative. Sonny is aimed to enlighten kids and bring them into this realm because he thinks by learning language and literature they will be able to define themselves. But on the other side, entering into this order means accepting the rules and dictates of society. The symbolic is made possible for the reason of your acceptance of the name of the Father. In the other word, it means the acceptance of those laws and restrictions that control not only your desire but also the rules of state. It is in this domain that ideology is inscribed and has effect. Ideology wipes out the function of language in the forming of the subject. Consequently, subjects misrecognize themselves the ways in which ideology interpolates them. They accept their positions dictated by ideology for participation in the social formation with pleasure. This subject is a subjected being. It means he is submitted to the dominance of social ideology. As Althusser asserts, "the Individual is interpellated as a (free) subject in order that he shall submit freely to the commandments of the Subject, i.e. in order that he shall (freely) accept his subjection." (1971, p.169)

In the novel we see there are events that can be experienced by black subject that cannot ever taken place to a white man. A school teacher like Sonny can speak only for the ordinary kids because the color restrictions impede him in the circumstances of his life. It happens to him from the day he started his subjectivity to the day he lives in the same context. The extent of his understanding of human situation is confined by the limits of his own social situation. Because it is bounded by class, social, economic and by color. How deep he can go for understanding the life around himself is an important question here. As a teacher he is not permitted to teach everything. Although he is indulged with the fact of education but there is lots of differences between what is going on in the society and what is happing in the schools and 
families. Sonny is blinded by his own circumstances. In the family he becomes isolated. It is expressed in this way, "Why did Aila never speak? Why did she never say what he wanted her to say?" (Gordimer, p.57). His quest of identity has entered into the false enchantment of his love affair thus,

\begin{abstract}
For commitment implies danger, and the blind primal instinct is to ensure the species survives in circumstances of danger...

In this freak displacement, the biological drive of his life, which belonged with his wife and the children he'd begotten, was diverted to his lover. He and Hannah begot no child; the revolutionary movement was to be their survivor. The excitement of their mating was for that. (Gordimer, p. 241-42)
\end{abstract}

Instead of knowing the impacts of his double life upon his family, he thinks that his family cannot support his revolutionary ideas. The novel makes clear this fact that revolutionary ideas of Sonny should change his own view point at first. It clarifies through the experiences of Sonny and his family members the ways of acquiring subjectivity in the then society of South Africa and the methods of curbing the same by the prevailed ideology. Gordimer depicts the life under the shadow of ISAs. In Gordimer's fictional world, characters are not able to acquire their freedom under the apartheid system. This issue hovers over every relationship within family, school, and in society as a whole. In the novel the idea of freedom is only an ideological interpretation. It is used by both those in charge and also common subjects to justify their subjectivity. Sonny's notion that by acquiring education they can finally achieve freedom is illusory. This only assists him in keeping himself in line while reinforcing the power of the ruling class. As such Bonnie Brennen believes,

The ideology of freedom is lived by both the elite and the working class and traps both groups in asset of relationships that are necessary to justify their specific material conditions of existence. Althusser's understanding of freedom as an ideological creation not only privileges he role of ideology in the construction of social relationships, but also calls into question the complex relationships between media, society, and freedom. $(2000$, p.6)

Sonny has been teaching young generation the writing skills, reading comprehension and math. His family members including himself are colored. They must act in accordance with the restrictions of the State's race regulations. Sonny is not permitted to participate in his city's political arguments. He is not authorized also to join cultural institutions and use the library as well. But he feels good while in the family and in the school. He is happy of being a part of an amicable whole. Step by step, his social conscience drives him into political activities. His family moves into a white suburb of Johannesburg. In those days it was a strategy compromised by those in charge of the movement. Sonny abandons his job as he is more obsessed with the future of the movement instead of the future of the young generation. As his sense of responsibility towards the political movement grows, he becomes increasingly estranged from his family and the common subjects as well. For their safety as well as his own, he avoids from discussing about his role in the movement, and he begins spending more time outdoors. Due to his participation in anti-government actions he was sentenced to two years prison. It was during his time in prison that he falls in love with a white lady named Hannah Plowman. He feels, "the ultimate joy of making love with someone who, too, is in the battle, for whom the people in the battle are her only family, her life, the happiness she understands" (Gordimer, p.52). Gordimer gives a brilliant depiction of the ambiguities of the two relationships, personal feelings, and their impacts upon ideology of theirs. She brings to the light questions such as in what ways have his actions affected his children's ideological stances? Or how far his feelings toward Hannah affected by the fact that she is a white subject?

It is ideology that calls to individuals and turns them into subject. From Althusser's view point, it is very difficult to get outside of ideology. He admirably explain this thus, "What thus seems to take place outside ideology (to be precise, in the street), in reality takes place in ideology. What really takes place in ideology seems therefore to take place outside of it. That is why those who are in ideology believe themselves by definition outside of ideology." (1971, p.75)

By the end of the story we learn the narrator- Sonny's son, Will- is not unbiased. At least some part of this story is Will's imagination. Such a position raises some questions about the false subjectivity that Sonny acquires by the end of the novel. It brings to the light the theme of betrayal. The way men betray women and the ways children betray their parents and most important to our discussion is the ways political leaders betray their one another. What actually Sonny wants exists outside him. Lacan named this the Other. Sonny's sensation towards his subjectivity returns to him unconsciously. What he does is not exactly what he wants. As Lemaire remarks, "Demand is never more than a metonymy of desire" (1977, p. 64). The subjectivity that Sonny gains at the end has been borrowed from somewhere else. It has been borrowed from the whites (Other). He is driven by dire necessity. He is under the influence of unconscious desire, that's why he is unsatisfied with his marital life and looks for unrecognized ways, for change. The issue here is not whether he acts wrong or right but rather the knowledge that ideological methods are placed into the 
anti-government movement as well. The point here is that such a kind of ideologies has been placed by the leaders of the movements even without minimal questioning or concern. With regard to the acceptance of these ideological messages Brennen rightly remarks,

\begin{abstract}
Once ideological messages are incorporated into society, it becomes virtually impossible to get outside of them, to question their validity or morality, without being written off as socially deviant. When become part of our common sense they begin to seem natural and normal beliefs that can help us to understand and actively participate in or complex contemporary culture. $(2000, p .13)$
\end{abstract}

Sonny's predicament gives this sensation that everything in society results from human activity, interaction and interests. Gordimer in her concern of the moral injustice of people like Sonny, depicts people oppressed in generally hopeless conditions. My Son's Story is the metaphoric portrayal of subjects who are either in anxiety for being divided from the majority of the people-like whites-or be afflicted because of imposed impoverishment like black masses. The writer questions the predicaments of her society noticeable by racial discrimination. It is through these narratives that Gordimer challenges oppression and fight for real freedom. Her writing gives a brilliant depiction of the depths of her people's consciousness.

Generally women play a major role in her fictional world. It is in the light of females' psyche that we can appreciate the physical and psychological conditions of the country. Most of the women are not satisfied with their life in both domains either in the family or in the social. But the point is that it is exactly in this uncertainty and unhappiness that lays the chance of transformation. Characters such as Aila and Hannah present particular kinds of women, and offer us particular roles of women (as a mother, and as a girlfriend). The point is that their depiction suggests individuals with significant capabilities. The way in which they are playing role is important because it can influence the audience's perceptions of them. My Son's Story twists reality in the sense that it convinces us that this is the way the society is. Sonny's home becomes his space of isolation. He thinks his family is not interested to support him in his revolutionary acts but the real reason is somewhere else. The real reason is that he himself is not a true leader and a reliable husband. As a father he should share his intentions with the family.

The isolation which Sonny receives from his family is in fact the result of driving a double life. As a matter of fact, the incorporation of an illicit love affair unmasks the manipulation of public opinion. This love affair can be considered as a cultural form. These sorts of forms are modes of representation of reality. These modes by invoking criteria of taste represent the correct way of life. Sonny thinks that by falling in love with a white lady he is bestowed the pass of freedom. Because there are only few black man who achieved such freedom. It is exactly here that Gordimer wants the reader to see if such ideology in the society has twisted the reality. It is this twist of reality that is called ideology and is viewed a key concept in Althusserian Marxism.

Sonny by his affair with Hannah believed that the order of inequality in society is natural. This relationship in the real sense is a veil that prevents subjects like Sonny from proper understanding. That is why Marx called it false consciousness. It is this system of value that he lives by, through which he perceives the society as well. This is ideology or as Althusser says ISA because it masks the real reason behind Sonny's dissatisfaction with his family.

Ideology in My Son's Story works at an unconscious level. The culture proposes that Sonny is free to choose between Aila and Hannah. However, Sonny has been convinced to choose a particular way of life. In this he is not really free. For ideology to be effective it has to be invisible, and this is where it comes in. Sonny's escape from his family responsibility has been justified through his illicit love affair. He thinks that his wife can not share his political zeal.

\title{
3. Conclusion
}

My Son's Story through the struggles of a colored man named Sonny depicts the relationship between resistance and freedom. The novel illustrates the impacts of prevailed ideologies upon the psyche of a common subject. Gordimer calls into question the complex interaction between education, equality, and freedom. Sonny the protagonist in his search for subjectivity values freedom over equality. His experiences show imaginary versions of real social apparatuses which constitutes ideology. From Althusserian view point, the ideology is apparent in the choices that Sonny made in his life. It is also obvious in his relationship with the family. His illicit love affair obscures the real conditions of his fights for freedom by presenting partial truths.

He is not able to attain full subjectivity for the reason that he was beguiled by his love for Hannah. Although he feels ultimate happiness while with Hannah but in the real sense his personal feelings have affected his ideological commitments. In the fictional world of Gordimer ideology is always circulated through specific apparatuses in society. It is 
the idea which the writer shares with Althusser. Gordimer proposed that the best and true freedom is freedom of mind and psyche. In the novel, idea of freedom is material because it works through the institutions such as family and schools. At the end, Sonny has been made to accept reality because he chooses to live within it. As a matter of fact, he is not aware of it because it has masked unequal social relationship.

\section{References}

Althusser, L. (1971). Lenin and Philosophy and Other Essays. tr. Ben Brewster.London: New Left Books.

Althusser, L. (2004). Ideology and Ideological State Apparatuses. In Julie Rivkin and Michael Ryan (Ed.). Literary Theory: An Anthology. Oxford: Blackwell.

Belsey, C. (1988). Critical Practice. London: Routledge.

Benveniste, E. (1971). Problems in General Linguistics. Miami: University of Miami Press.

Brennen. B. (2000). Communication and Fredom: An Althusserian Reading of Media Government Relations. The public, Vol.7 (4): 5-15.

Clingman, S. (1986). The novels of Nadine Gordimer: History from the inside. Amherest: Massachausetts UP.

Coward, R. and Ellis, J. (1977). Language and Materialism. London: Routledge.

Derrida, J. (1973). 'Differance', Speech and Phenomena and other Essays on Husserl's Theory of Signs, tr. David B.Allison. Evanston, IL: Northwestern University Press.

Gordimer, N. (1990). My Son's Story. Great Bretain. Bloomsbury.

Lemaire, A. (1977). Jacques Lacan, tr. David Macey. London: Routledge. 